\title{
Hypertonia Assessment Tool - użyteczne narzędzie do rózinicowania wygórowanego napięcia mięśniowego u pacjentów pediatrycznych
}

\section{Hypertonia Assessment Tool - useful tool for assessing muscle tone in pediatric patients}

\author{
Maria Ferenstein* (D), Tomasz A. Piotrowski* (D), Matgorzata J. Stańczyk*iD, Edyta Tekień * (D), Jakub S. \\ Gąsior**iD \\ *Oddział Fizjoterapii, Wydział Medyczny, Warszawski Uniwersytet Medyczny \\ **Klinika Kardiologii Wieku Dziecięcego i Pediatrii Ogólnej, Warszawski Uniwersytet Medyczny \\ DOI:10.20966/chn.2020.58.458
}

\section{STRESZCZENIE}

Hypertonia Assessment Tool (HAT) stanowi użyteczne narzędzie do oceny i klasyfikacji wygórowanego napięcia mięśniowego, i może być stosowane podczas badania pacjentów pediatrycznych z zaburzeniami neurologicznymi. Prawidłowa ocena rodzaju hipertonii (dystonia, spastyczność, sztywność) jest kluczowa w doborze odpowiedniego leczenia i ustalania programu rehabilitacji. Celem pracy było omówienie praktycznego wykorzystania narzędzia HAT u pacjentów pediatrycznych oraz dokonanie przeglądu piśmiennictwa badań wykorzystujących to narzędzie do oceny napięcia mięśniowego. Przegląd piśmiennictwa przeprowadzono zgodnie z rekomendacjami PRISMA przeszukując medyczną bazę danych Pubmed. Uwzględniono jedynie publikacje anglojęzyczne. Zidentyfikowano 5 publikacji spełniających powyższe kryteria, oraz jeden komentarz. Autorzy włączonych badań sugerują, że HAT jest przydatne do wykrywania sztywności i spastyczności, natomiast przy dystonii zaleca się dokładniejszą analizę i modyfikację użycia tego narzędzia. HAT charakteryzuje się dobrą wiarygodnością i trafnością w identyfikacji spastyczności i braku sztywności, a także umiarkowaną dokładności rozpoznawczą w przypadku dystonii. Przedstawiony artykuł przedstawia ttumaczenie własne kwestionariusza wykorzystywanego podczas badania hipertonii oraz opis konstrukcji i zalet narzędzia. Zaleca się wykorzystywanie narzędzia HAT do oceny rodzaju podwyższonego napięcia mięśniowego u pacjentów pediatrycznych z zaburzeniami neurologicznymi.

Słowa kluczowe: hipertonia, mózgowe porażenie dziecięce, spastyczność, dystonia, sztywność, Hypertonia Assessment Tool.
ABSTRACT

The Hypertonia Assessment Tool (HAT) as a tool to assess excessive muscle tone should be an important part of the neurological examination. The correct classification of the type of hypertonia (dystonia, spasticity, rigidity) is used to adjust the appropriate treatment and to establish rehabilitation goals. The aim of the study was to discuss the practical use of the tool for assessing muscle tone in paediatric patients and to review the existing literature on HAT. Literature review was performed according to PRISMA recommendations by searching the Pubmed database. Only English-language publications were taken into account. Five articles meeting the above criteria and one commentary were identified. It was suggested that HAT is useful for the detection of rigidity and spasticity, while for dystonia it is recommended to analyze and modify this tool more thoroughly. HAT presented good reliability and validity in identification of spasticity and lack of rigidity as well as moderate results in case of dystonia. The article presents translation of HAT assessment and description of the advantages of the tool. HAT is recommended to assess the type of hypertonia in pediatric patients with neurological disorders.

Key words: hypertonia, cerebral palsy, spasticity, dystonia, rigidity, Hypertonia Assessment Tool.

\section{INTRODUKCJA}

W praktyce klinicznej napięcie mięśniowe definiuje się jako występowanie oporu na bierne rozciąganie grupy mięśniowej, podczas gdy świadomy pacjent stara się utrzymać mięśnie $\mathrm{w}$ rozluźnieniu. Wygórowane napięcie mięśniowe (hipertonia) jest jednym z rodzajów zaburzeń napięcia mięśniowego objawiającym się wzmożonym oporem na zewnętrzne siły działające na dany staw. Mechanizmy (rozumiane w tej pracy jako uszkodzenie ośrodkowego układu nerwowego) prowadzące do zwiększonego napięcia mięśniowego mogą przyczyniać się do osłabionej sprawności ruchowej lub mimowolnych skurczów mięśni. Niemniej jednak, ocena napięcia mięśniowego jest niezależna od siły, zręczności, koordynacji lub ruchów mimowolnych [1].
W diagnostyce klinicznej wyróżnia się trzy typy hipertonii: spastyczność, dystonię i sztywność [1]. Typy te mogą występować osobno lub w połączeniu. Diagnozując spastyczność należy zaobserwować przynajmniej jeden z następujących objawów: 1) opór na rozciąganie stawiany przez mięsień/grupę mięśniową zwiększa się wraz ze wzrostem prędkości rozciągania mięśnia i zmienia się w zależności od kierunku ruchu stawu; 2) opór na rozciąganie stawiany przez mięsień gwałtownie wzrasta po przekroczeniu prędkości progowej lub określonego kąta w stawie [1].

Dystonia to mimowolna zmiana $\mathrm{w}$ pobudzeniu mięśnia podczas świadomego ruchu lub podczas utrzymywania postawy, którą diagnozuje się poprzez zaobserwowanie nietypowych skrętnych postaw lub powtarzających się ruchów. 
Dystonia jest powszechnie wywoływana lub zaostrzana przez próby świadomego ruchu oraz może często się zmieniać w czasie i pogarszać wraz z upływem czasu. Ciężkość i jakość dystonii mogą różnić się zależnie od pozycji ciała, specyficznych zadań, stanu emocjonalnego, czy poziomu świadomości [1].

Sztywność zdefiniowana jest jako rodzaj hipertonii, w której wszystkie z następujących obserwacji są spełnione: 1) opór na zewnętrznie narzucony ruch jest obecny przy bardzo małych prędkościach ruchu i nie wykazuje progu kątowego; 2) ewentualne pojawienie się jednoczesnego skurczu agonistów i antagonistów znajduje odzwierciedlenie w natychmiastowym oporze w odwróconym kierunku ruchu stawowego; 3) kończyna nie ma tendencji do powrotu do stałej określonej pozycji lub skrajnego ustawienia kątowego w stawie; 4) dobrowolna aktywność w odległych grupach mięśniowych nie prowadzi do mimowolnych ruchów w zajętych stawach, chociaż sztywność może się pogorszyć [1].

Odpowiednia identyfikacja typu hipertonii jest niezbędna, aby odpowiednio dostosować program leczenia i rehabilitacji. Jednym z narzędzi służących do diagnozy hipertonii, ale także pomocnym w różnicowaniu typów wygórowanego napięcia mięśniowego jest Hypertonia Assessment Tools (HAT) [2]. Celem pracy jest przedstawienie oraz omówienie na podstawie przeglądu piśmiennictwa zagadnienia praktycznego wykorzystania HAT do oceny napięcia mięśniowego u pacjentów pediatrycznych.

\section{MATERIAŁ I METODY}

Przegląd piśmiennictwa przeprowadzono zgodnie $\mathrm{z}$ rekomendacjami Preferred Reporting Items for Systematic Reviews and Meta-Analyses (PRISMA) Statement [3]. Proces wyszukiwania publikacji naukowych przeprowadzono z użyciem medycznej bazy danych PubMed wpisując hasło kluczowe „hypertonia assessment tool” (link do wyszukiwania zastosowany dnia: 13.07.2020 r.: https:// pubmed.ncbi.nlm.nih.gov/?term $=\% 22$ hypertonia + assessm ent+tool $\% 22 \&$ sort=pubdate) Zidentyfikowano 6 publikacji naukowych [2, 4-7]: 4 prace badawcze, jeden artykuł przeglądowy oraz jeden komentarz. W Tabeli I zaprezentowano cele badawcze, opis grupy badanej oraz uzyskane wyniki włączonych do analizy badań. Włączone prace były analizowane przez wszystkich autorów przeglądu. Rozbieżności pomiędzy autorami były rozstrzygane poprzez dyskusję.

\section{WYNIKI}

W uwzględnionych publikacjach przebadano łącznie 284 uczestników. U 269 zdiagnozowano mózgowe porażenie dziecięce (MPD), u 11 urazy głowy/mózgu, a u 4 pozostałych zaburzenia neuromotoryczne o różnej etiologii. Szczegóły dotyczące charakterystyki pacjentów oraz skal i parametrów wykorzystanych podczas badań zaprezentowano w tabeli I.

\section{DYSKUSJA}

Hipertonia jest najczęściej wynikiem zaburzeń występujących w obrębie ośrodkowego układu nerwowego
(OUN), lub chorób nerwowomięśniowych, których konsekwencją są nieprawidłowości w rozwijających się ścieżkach motorycznych w korze mózgowej, jądrach podstawnych, pniu mózgu, móżdżku i rdzeniu kręgowym [8]. Według niektórych autorów, niemożliwym jest ustalenie konkretnego neuroanatomicznego miejsca uszkodzenia OUN na podstawie samego badania fizykalnego noworodka lub niemowlęcia [8]. Czas pojawienia się wygórowanego napięcia mięśniowego może być kluczowy dla diagnostyki rozwijających się zaburzeń mózgu [8]. Hipertonię można podzielić na trzy typy: spastyczność, dystonię i sztywność [5]. Opisane w publikacjach definicje umożliwiają ich identyfikację. Wykorzystując narzędzie HAT można zdiagnozować, który z podtypów hipertonii występuje u danego pacjenta.

Ocena wygórowanego napięcia mięśniowego w warunkach klinicznych jest trudnym zadaniem, ponieważ jedyną dostępną informacją jest związek pomiędzy pasywnym ruchem w stawie, a momentem obrotowym odczuwalnym przez badającego. Ważnym elementem oceny, którego brakuje w rutynowych badaniach klinicznych, jest stan aktywacji mięśni niewidoczny przy ocenie wizualnej. Sanger i wsp. [9] sugerują, że użycie badania elektromiograficznego (EMG) może znacznie poprawić niezawodność oceny hipertonii u dzieci. Badając napięcie mięśniowe u zdrowej osoby odczuwany jest opór składający się z dwóch głównych komponentów: elastyczności więzadeł, ścięgien, oraz aktywnego skurczu mięśniowego. Napięcie mięśniowe może być inne w poszczególnych częściach ciała jak również zmieniać się z biegiem czasu. Zależy od wielu zewnętrznych jak i wewnętrznych czynników, takich jak np. stan emocjonalny, dyskomfort związany z zaparciami, ból czy niepokój [10]. Zawsze należy brać pod uwagę potencjalne czynniki powodujące zwiększenie napięcia mięśniowego [9].

Istnieje wiele miar klinicznych opisujących spastyczność (np.: zmodyfikowana skala Ashwortha, skala Tardieu). Obecność dystonii oceniana jest za pomocą skali Barry'ego Albrighta [10], czy skali Burke-Fahn-Marsden Dystonia Rating Scale [10]. Narzędzie HAT do oceny podwyższonego napięcia mięśni składa się z siedmiu punktów/pozycji (Rycina I). Punkty 1, 2 i 6 służą do oceny objawów dystonii, punkty 3 i 4 pozwalają na zdiagnozowanie spastyczności, a punkty 5 i 7 sztywności. Każda z pozycji może zostać oceniona jako pozytywna lub negatywna (tak/ nie) [5]. Każda z kończyn jest obserwowana i uzyskuje indywidualną ocenę hipertonii. Obecność podtypu hipertonii jest potwierdzona pozytywnym wynikiem w co najmniej jednej pozycji [6]. Tłumaczenie własne kwestionariusza Hypertonia Assessment Tool zostało zaprezentowano na Rycinie 1.

Celem pracy było przedstawienie oraz omówienie na podstawie przeglądu piśmiennictwa zagadnienia praktycznego wykorzystania HAT do oceny napięcia mięśniowego u pacjentów pediatrycznych. Przy ustalonych kryteriach wyszukiwania włączono do szczegółowej analizy pięć publikacji [2, 4-7], które koncentrowały się głównie na sprawdzeniu wiarygodności skali u pacjentów ze zdiagnozowanym MPD. Zauważono, że HAT lepiej sprawdza się 
Tab. I. Przegląd badań dotyczących oceny napięcia mięśniowego za pomocą narzędzia HAT. Overview of studies on assessment muscle tone with the HAT

\begin{tabular}{|c|c|c|c|}
\hline $\begin{array}{l}\text { Pierwszy } \\
\text { autor, rok } \\
\text { badania } \\
\text { First author, } \\
\text { year of the } \\
\text { study }\end{array}$ & $\begin{array}{c}\text { Cel badania } \\
\text { Aim of the study }\end{array}$ & $\begin{array}{l}\text { Opis grupy eksperymentalnej } \\
\text { Description of the study group }\end{array}$ & $\begin{array}{l}\text { Wyniki } \\
\text { Results }\end{array}$ \\
\hline $\begin{array}{l}\text { Jethwa A., } \\
2010 \\
{[4]}\end{array}$ & $\begin{array}{l}\text { Opracowanie } \\
\text { narzędzia do } \\
\text { identyfikacji } \\
\text { podtypów } \\
\text { zwiększonego } \\
\text { napięcia mięśniowego } \\
\text { u dzieci. Badanie } \\
\text { oceny rzetelności } \\
\text { i powtarzalności } \\
\text { narzędzia HAT. }\end{array}$ & 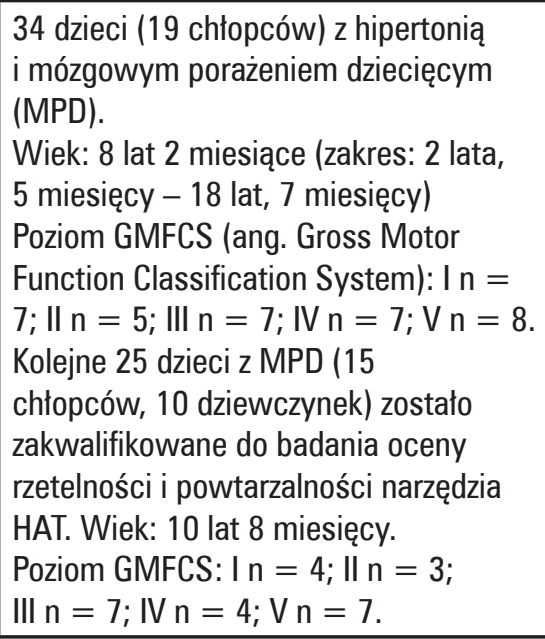 & $\begin{array}{l}\text { Narzędzie do oceny hipertonii } \\
\text { charakteryzuje się dobrą wiarygodnością } \\
\text { w identyfikacji spastyczności i braku } \\
\text { sztywności, a także umiarkowaną } \\
\text { rzetelnością w przypadku rozpoznawania } \\
\text { dystonii. } \\
\text { Częsta diagnoza obecności jednocześnie } \\
\text { zarówno spastyczności jak i dystonii } \\
\text { u większości dzieci z MPD. }\end{array}$ \\
\hline $\begin{array}{l}\text { Pavone L., } \\
2012 \\
\text { [2] }\end{array}$ & $\begin{array}{l}\text { Przegląd skal } \\
\text { klinicznych, pomiarów } \\
\text { kinematycznych } \\
\text { i funkcjonalnych } \\
\text { u dzieci z dystonią. }\end{array}$ & & $\begin{array}{l}\text { Praca opisuje narzędzie HAT. Według } \\
\text { autorów, HAT bardziej sprawdza się przy } \\
\text { występowaniu dystonii i spastyczności } \\
\text { niż przy ich braku. Z kolei przy obecności } \\
\text { sztywności narzędzie to lepiej diagnozuje } \\
\text { brak objawów. }\end{array}$ \\
\hline $\begin{array}{l}\text { Knights S., } \\
2012 \\
{[5]}\end{array}$ & $\begin{array}{l}\text { Określenie } \\
\text { wykorzystania analizy } \\
\text { nagrań wideo na } \\
\text { punktację, trafność } \\
\text { i rzetelność HAT oraz } \\
\text { przeprowadzenie } \\
\text { walidacji } \\
\text { poszczególnych } \\
\text { pozycji } \\
\text { i wyeliminowanie } \\
\text { wszelkich pozycji, } \\
\text { które nie przyczynity } \\
\text { się do rozpoznania } \\
\text { hipertonii. }\end{array}$ & $\begin{array}{l}28 \text { dzieci (17 chłopców). } \\
\text { Wiek: } 9 \text { lat (zakres: od } 4 \text { do } 17 \\
\text { roku życia). Wszyscy pacjenci ze } \\
\text { zdiagnozowaną hipertonię związaną z } \\
\text { MPD. } \\
\text { Hemiplegia } n=9 \text {, diplegia } n=19 \\
\text { Poziom GMFCS: In }=11 ; \text { II } n=5 ; \\
\text { III } n=4 ; \text { IV } n=3 ; \text { V } n=5 \\
\text { Poziom MACS (ang. Manual Ability } \\
\text { Classification System): I } n=12 ; \\
\text { II } n=10 ; \text { III } n=1 ; \text { IV } n=0, V n=5\end{array}$ & $\begin{array}{l}\text { Po przeglądzie zapisów wideo, wyniki } \\
\text { poszczególnych pozycji skali HAT były } \\
\text { zmieniane } 3 \text { razy dla pozycji } 1 \text { i } 2 \text { oraz } \\
4 \text { razy dla pozycji } 4 \text {. Wyniki nie były } \\
\text { zmieniane dla pozycji } 7 \text {. Sumarycznie } \\
\text { spowodowało to zmianę punktacji } \\
\text { poszczególnych pozycji o 4,5\% (10 zmian } \\
\text { na } 224 \text { pozycje ogółem). } \\
\text { Niezawodność skali była umiarkowana } \\
\text { dla dystonii (bias-adjusted kappa = } \\
\text { 0,43), doskonała dla spastyczności i } \\
\text { braku sztywności (kappa = 0,86-1,0). } \\
\text { Ważność kryterium była istotna dla } \\
\text { stwierdzenia spastyczności (kappa = } \\
\text { 0,71), umiarkowana dla stwierdzenia } \\
\text { dystonii (kappa = 0,43-0,57), doskonała } \\
\text { dla stwierdzenia braku sztywności } \\
\text { (kappa = 1,0). } \\
\text { Pomimo tych zmian w wynikach } \\
\text { punktowych, tylko w jednym przypadku } \\
\text { ogólna diagnoza hipertonii zmieniła się } \\
\text { po przeglądzie nagrań video. Pomimo } \\
\text { możliwości ponownego przeanalizowania } \\
\text { nagranej oceny subtelnych ruchów } \\
\text { dystonicznych, przegląd zapisu wideo } \\
\text { nie zmienił znacząco diagnozy hipertonii } \\
\text { poprzez HAT, ani nie poprawił wyników } \\
\text { psychometrycznych elementów dystonii. }\end{array}$ \\
\hline
\end{tabular}




\begin{tabular}{|c|c|c|c|}
\hline $\begin{array}{l}\text { Marisco P., } \\
2016 \\
{[6]}\end{array}$ & $\begin{array}{l}\text { Określenie rzetelności } \\
\text { i zasadności używania } \\
\text { HAT w chorobach } \\
\text { neuromotorycznych u } \\
\text { dzieci. }\end{array}$ & 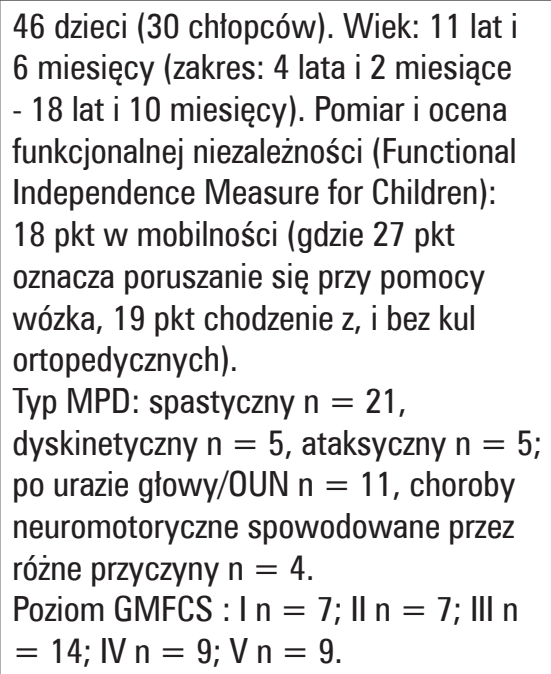 & $\begin{array}{l}\text { Mała zgodność w ocenie spastyczności } \\
\text { wykorzystując pozycję nr } 4 \\
\text { kwestionariusza HAT między dwoma } \\
\text { badaczami dokonującymi oceny dziecka } \\
\text { oznacza problem subiektywnej oceny } \\
\text { objawów spastyczności. Aby poprawić } \\
\text { właściwości psychometryczne zalecono } \\
\text { poprawienie i ujednolicenie wykonywania } \\
\text { testów i ocen oraz zapewnienie trening } \\
\text { osobom oceniającym. } \\
\text { HAT oferuje całkiem dobrze opisane } \\
\text { narzędzie służące do odróżnienia } \\
\text { występujących typów zwiększonego } \\
\text { napięcia mięśniowego w chorobach } \\
\text { neuromotorycznych dzieci. }\end{array}$ \\
\hline $\begin{array}{l}\text { Rice J., } 2017 \\
\text { [7] }\end{array}$ & $\begin{array}{l}\text { Ustalenie } \\
\text { rozpowszechnienia } \\
\text { i rodzaju ciężkości } \\
\text { dystonii wśród } \\
\text { populacji dzieci z } \\
\text { MPD przy użyciu } \\
\text { narzędzi do oceny i } \\
\text { pomiaru hipertonii. }\end{array}$ & $\begin{array}{l}151 \text { dzieci (84 chłopców). Wiek: } 9 \text { lat } \\
\text { (zakres: } 2-18 \text { rok życia) } \\
95 \% \text { dzieci widniało w krajowym } \\
\text { rejestrze osób z MPD, pozostałe } 5 \% \\
\text { mieszkało poza stanem lub nie wyraziło } \\
\text { zgody na rejestrację. }\end{array}$ & $\begin{array}{l}\text { Według dominującego typu } \\
\text { motorycznego (PMT - predominant } \\
\text { motor type) 85\% pacjentów miało } \\
\text { postać spastyczną, 14\% dyskinetyczną } \\
\text { i 1\% ataktyczną. Według oceny HAT } \\
\text { i skali nasilenia dystonii (BAD, Barry- } \\
\text { Albright Dystonia) grupy spastyczne i } \\
\text { dyskinetyczne wykazywały powszechne } \\
\text { dowody dystonii. Dyskinetyczna grupa } \\
\text { miała większy średni wynik w skali } \\
\text { BAD niż grupa spastyczna (różnica o } 13 \\
\text { jednostek, 95\% Cl 9.1-16.4). Nasilenie } \\
\text { dystonii (wynik BAD) zwiększało się } \\
\text { liniowo w odniesieniu do motoryki dużej } \\
\text { (p < 0.001), zdolności manualnych } \\
\text { (p < 0.001) i poziomów komunikacji } \\
\text { funkcjonalnej (p < 0.001). } \\
\text { Porównując kończyny górne i dolne za } \\
\text { pomocą narzędzia HAT zanotowano } \\
\text { wyraźne różnice. Zgodność między } \\
\text { wszystkimi czterema kończynami } \\
\text { była bardzo niska (kappa = 0.12, 95\% } \\
\text { Cl 0.08-0.17). Wyniki sugerują, że } \\
\text { pojedyncza ocena HAT kończyny górnej } \\
\text { może nie być wystarczająca. } \\
\text { Zauważono także rozbieżność dla pozycji } \\
\text { nr } 6 \text { kwestionariusza HAT w identyfikacji } \\
\text { dystonii w porównaniu z pozycjami } 1 \text { i } 2 . \\
\text { Pozycja nr } 6 \text { wg HAT wykazała } \\
\text { najmniejszy związek ze skalą BAD (kappa } \\
=0.01-0.38 \text { ). }\end{array}$ \\
\hline
\end{tabular}

przy obecności dystonii i spastyczności niż przy ich braku [2]. Z kolei przy obecności sztywności narzędzie to lepiej diagnozuje brak objawów, niż ich obecność. Z analizy artykułów wynika również, że HAT charakteryzuje się dobrą wiarygodnością i trafnością w identyfikacji spastyczności i braku sztywności, a także umiarkowanymi wynikami w przypadku dystonii. Stosowanie nagrań wideo podczas badania nie jest konieczne, gdyż jak pokazuje Knightsa i wsp. [5] ponowne przeanalizowanie nagranej oceny subtelnych ruchów dystonicznych nie zmienia znacząco dia- gnozy hipertonii z wykorzystaniem HAT. Niemniej jednak, autorzy podkreślają korzyści z możliwości ponownego odtworzenia i przeanalizowania badania [5].

Odpowiednie zdiagnozowanie typu hipertonii jest niezwykle ważne, by jak najlepiej zaplanować odpowiednie leczenie pacjenta oraz proces jego rehabilitacji. Zgodnie z zasadami Medycyny Opartej na Dowodach Naukowych (EBM, ang. evidence based medicine) w każdym postępowaniu klinicznym należy odwoływać się do wiarygodnych i aktualnych źródeł, dlatego zarówno w procesie diagno- 
Rycina 1. Kwestionariusz oceny hipertonii według narzędzia HAT (tłumaczenie własne z [4]). Questionnaire for assessing muscle tone according to the HAT.

\section{Narzędzie do oceny hipertonii - HAT (ang. hypertonia assessment tool) Tabela punktowa}

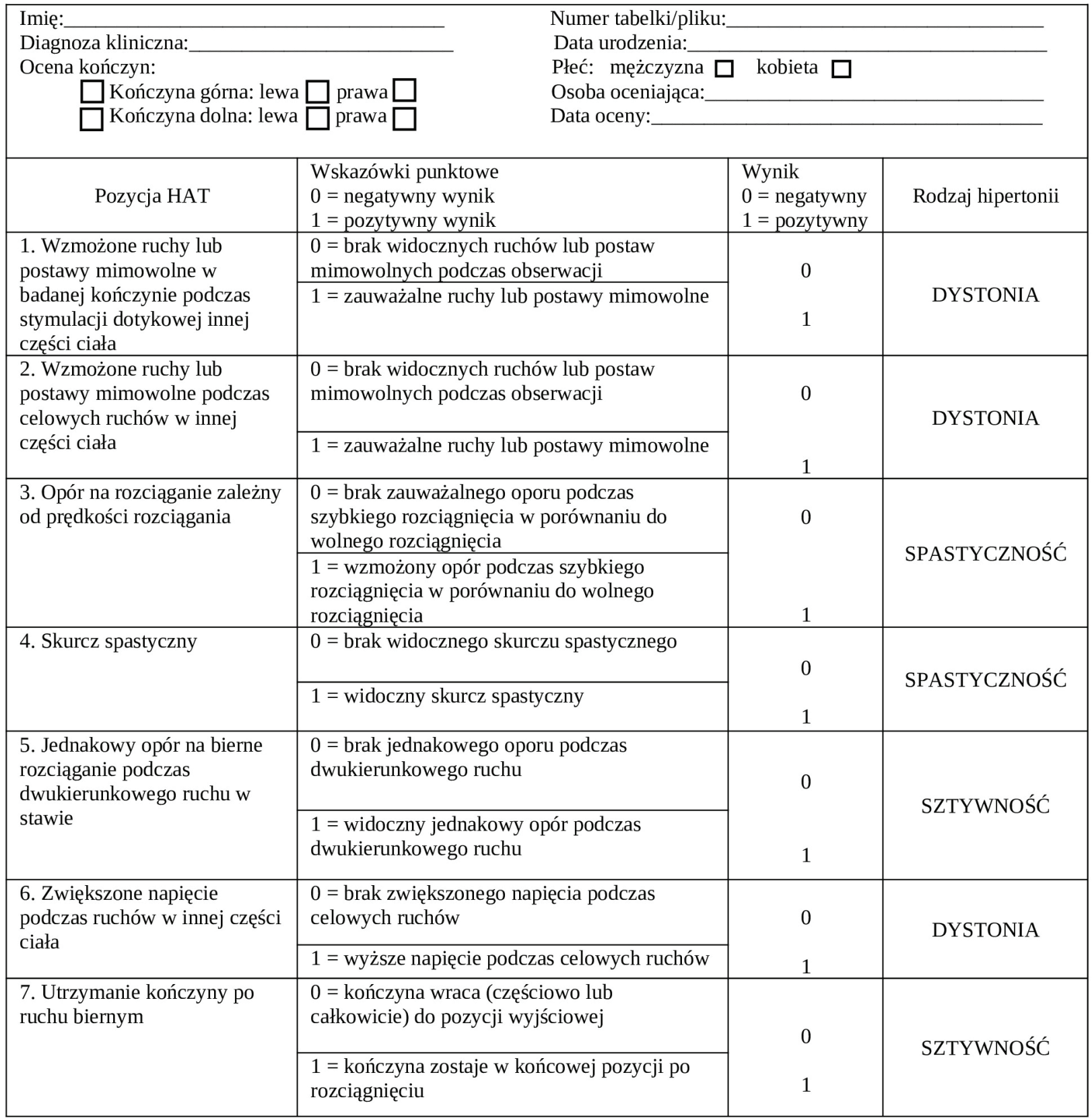

PODSUMOWANIE WYNIKÓW - DIAGNOZA HAT

\begin{tabular}{|l|l|}
\hline & Zaznaczyć wybrane \\
\hline DYSTONIA $\longrightarrow$ Wynik pozytywny (1) przynajmniej w jednej pozycji \#1,2 lub 6 & $\square$ Tak $\square$ Nie \\
SPASTYCZNOŚć $\longrightarrow$ Wynik pozytywny (1) w jednej lub obu pozycjach \#3 lub 4 & $\square$ Tak $\square$ Nie \\
SZTYWNOŚĆ $\longrightarrow$ Wynik pozytywny (1) w jednej lub obu pozycjach \#5 lub 7 & $\square$ Tak $\square$ Nie \\
MIESZANE NAPIĘCIE $\longrightarrow$ Obecność jednego lub więcej podtypów & $\square$ Tak $\square$ Nie \\
\hline
\end{tabular}

stycznym jak i w dalszym planowaniu terapii, szczególną uwagę powinno poświęcić się metodologii pomiarów i kryteriom oceny efektów leczenia.

W 2001 roku Światowa Organizacja Zdrowia (WHO, ang. World Health Organization) wprowadziła Między- narodową Klasyfikację Funkcjonowania, Niepełnosprawności i Zdrowia (ICF, ang. International Classification of Functioning, Disability and Health) co pozwoliło na ujednolicenie, zgromadzenie i porównanie informacji o stanie zdrowia osób niepełnosprawnych z całego świata [11]. 
U dzieci z hipertonią podwyższone napięcie mięśniowe nie jest głównym problemem. Największe trudności związane są z konsekwencjami wygórowanego napięcia mięśniowego, tj. z zaburzeniami funkcji, wtórnymi powikłania, dysfunkcjami stawów, zmęczeniem, zaburzeniami snu, zmniejszonym poczuciem bezpieczeństwa, ograniczoną samodzielnością ruchową, obniżoną jakością życia oraz towarzyszącym bólem [12]. W czynnościach dnia codziennego dziecko musi zmagać się z niekontrolowanymi skurczami i zmniejszonym zakresem ruchu w stawach. Mała kontrola nad wykonywanym ruchem obniża funkcjonalność kończyn.

W leczeniu hipertonii ważną rolę odgrywa dokładne wyznaczenie celów terapii. Precyzyjnie określone cele pozytywnie wpływają na efekt leczenia na poziomie strukturalnym oraz aktywności pacjenta, a także w wielu przypadkach na umożliwienie wykonywania czynności pielęgnacyjnych przez rodzica lub opiekuna dziecka [13]. Powinny być one ustalone wspólnie z rodzicami, którzy wiedzą z jakim problemem spotyka się dziecko. Stawiane zadania muszą być jednak realne do osiągnięcia [10]. Wygórowane napięcie mięśniowe znacznie wpływa na strukturę układu mięśniowo-szkieletowego, co pośrednio wpływa na pozostałe płaszczyzny ICF, czyli aktywność oraz partycypację. Na płaszczyźnie aktywności u dzieci z zaburzeniami neurologicznymi, obserwowane są nieprawidłowości chodu, które mają podłoże w niewłaściwym sterowaniu ruchami dziecka i są skutkiem uszkodzenia OUN oraz uruchamianych mechanizmów kompensacyjnych [14]. Do pierwotnych objawów uszkodzenia OUN wpływających na nieprawidłowy rozwój chodu zalicza się: brak selektywnej kontroli motorycznej (zwłaszcza w dystalnych częściach kończyn dolnych), osłabienie reakcji równoważnych, zaburzenia sensoryczne, niewłaściwy rozkład i wielkość napięcia posturalnego oraz brak równowagi mięśniowej pomiędzy aktywnością mięśni agonistycznych i antagonistycznych [14]. Skutkiem działania tych czynników jest wystąpienie nieprawidłowych sił działających na układ mięśniowo-szkieletowy, co w konsekwencji przyczynia się do wystąpienia objawów drugorzędowych: przykurczów, deformacji kostnych oraz rozwoju zwichnięcia lub podwichnięcia w stawach [14]. Powyższe deformacje, wraz z czasem utrwalają się i powodują zaburzenia wzorca chodu, który może różnić się wśród pacjentów w zależności od stopnia uszkodzenia OUN. Chód tych dzieci staje się niestabilny, niepłynny i nieergonomiczny, co na płaszczyźnie partycypacji powoduje, że pacjent nie uczestniczy w aktywnościach i zabawach dnia codziennego.

Leczenie hipertonii to wielodyscyplinarny wysiłek uwzględniający kilka czynników włączając w to cele funkcjonalne pacjenta, a także potrzeby rodziców lub opiekunów [15]. Nie ma jednego złotego standardu leczenia hipertonii. Wybór terapii powinien być indywidualny, zależny od oceny poziomu/typu hipertonii. Opcje leczenia mogą być pogrupowane w następujące kategorie: farmakoterapia, fizjoterapia, leczenie operacyjne $\mathrm{i}$ inne alternatywne metody terapii [12]. Uogólniona hipertonia jest często leczona lekami doustnymi. Udokumentowano, że leczenie farmako- logiczne (np. baclofen, diazepam) skutecznie obniża spastyczność, niemniej jednak, jako wyizolowana forma terapii niejednoznacznie wpływa na poprawę funkcji [13].

Często w połączeniu $\mathrm{z}$ doustnym/ogólnoustrojowym leczeniem farmakologicznym wykorzystywane są miejscowe iniekcje toksyny botulinowej szczególnie u dzieci i młodzieży z mieszanym typem hipertonii [13]. W ciągu ostatnich dwudziestu lat terapia z wykorzystaniem iniekcji toksyny botulinowej stała się integralną częścią zestawu narzędzi terapeutycznych w leczeniu spastyczności i dystonii u dzieci z MPD [13]. Skuteczność leczenia z wykorzystaniem toksyny botulinowej została odnotowana w zmniejszeniu spastyczności, a w konsekwencji w zapobieganiu wtórnym deformacjom mięśniowo-szkieletowym i przykurczom stawów oraz prawdopodobnie opóźnianiu konieczności wykonania zabiegu chirurgicznego, zmniejszaniu bólu, poprawie higieny, zmniejszaniu obciążenia opiekuna, ułatwieniu funkcji i wspieraniu rozwoju motoryki pacjenta [13]. Jednak spastyczność jest tylko jednym z następstw uszkodzenia zespołu górnego neuronu ruchowego. Osłabienie i zaburzona regulacja siły mięśniowej, upośledzone planowanie i kontrola motoryczna, zaburzona koordynacja przyczyniają się do ogólnego upośledzenia funkcji motorycznych i należy je również wziąć pod uwagę przy formułowaniu celu leczenia.

Zabiegi ortopedyczne u pacjentów z hipertonią są stosowane od wielu lat i cechują się satysfakcjonującą efektywnością [16]. Najbardziej popularnymi zabiegami są wydłużanie ścięgien i tenotomia, które mogą skutkować ponownym rozciągnięciem jednostki mięśniowo-ścięgnistej i dostosowaniem długości sarkomeru umożliwiając generowanie większej siły mięśniowej [16].

Istnieją badania sugerujące pozytywne efekty zabiegu selektywnej rizotomii grzbietowej u wybranych pacjentów [17-19]. Jednakże, badania te nie stwierdzają korzyści względem dystonii, a nawet opisywane jest pogorszenie objawów, dlatego konieczne jest, aby przed zabiegiem rizotomii wykluczyć takie rozpoznanie. Ortezy mogą być bardzo pomocne w poprawie jakości chodu, ale ważne jest aby nie zaniedbywać wzmacniania odpowiednich grup mięśniowych. Dlatego u niektórych dzieci ważne jest, aby zaopatrzenie ortopedyczne nie było noszone w sposób ciągły, lecz w ustalonych okresach czasu [16].

W warunkach klinicznych i badawczych, HAT może być stosowane w celu lepszego klasyfikowania podtypów hipertonii uczestników badań i przedstawiania konkretnych wyników. Według badania Rica i wsp. [7] zgodność w diagnozie hipertonii w zakresie kończyn górnych i dolnych była wyraźnie różna, oraz nastąpiła duża rozbieżność. Okazuje się, że punkt 6 identyfikuje inny aspekt dystonii poprzez palpację wzmożonego napięcia mięśniowego przy aktywnych ruchach kończyn, zaś punkty 1 i 2 skupiają się na ruchach mimowolnych. Rekomendowano usunięcie punktu $6 \mathrm{z}$ narzędzia [7]. Tylko w jednym z powyższych artykułów przebadano pacjentów poniżej 4 roku życia. Ostatnio podkreślono istotność i konieczność prowadzenia dalszych badań dotyczących walidacji narzędzi badawczych do oceny spastyczności u pacjentów z wysokim ry- 
zykiem lub ze zdiagnozowanym MPD poniżej 2 roku życia [20]. Brakuje danych, które potwierdzałyby przydatność Hypertonia Assessment Tool do oceny hipertonii u dzieci do 4 roku życia. Warto poszerzyć badania użyteczności skali do oceny napięcia mięśniowego u pacjentów pediatrycznych w młodszym wieku, by jak najszybciej wykryć nieprawidłowości i zaplanować odpowiednie leczenie.

\section{PIŚMIENNICTWO}

[1] Sanger T.D.; Delgado M.R.; Gaebler-Spira D., et al.: Classification and Definition of Disorders Causing Hypertonia in Childhood. Pediatrics 2003; 111: 89-97.

[2] Pavone L., Burton J., Gaebler-Spira D.: Dystonia in Childhood: Clinical and Objective Measures and Functional Implications. J Child Neurol 2013; 28: $340-350$.

[3] Moher D., Liberati A., Tetzlaff J., et al.: Preferred reporting items for systematic reviews and meta-analyses: the PRISMA statement. BMJ 2009; 21: 339.

[4] Jethwa A., Mink J., Macarthur C., et al.: Development of the Hypertonia Assessment Tool (HAT): a discriminative tool for hypertonia in children 2009. Dev Med Child Neurol 2010; 52: 83-87.

[5] Knights S., Datoo N., Kawamura A., et al.: Further Evaluation of the Scoring, Reliability, and Validity of the Hypertonia Assessment Tool (HAT). J Child Neurol 2014; 29: 500-504.

[6] Marsico P., Frontzek-Weps V., Balzer J., et al.: Hypertonia Assessment Tool: Reliability and Validity in Children With Neuromotor Disorders. J Child Neurol 2017; 32: 132-138.

[7] Rice J., Skuza P., Baker F., et al.: Identification and measurement of dystonia in cerebral palsy. Dev Med Child Neurol 2017; 59: 1249-1255.
[8] Hart A.R., Sharma R., Rittey C.D., et al.: Neonatal hypertonia - a diagnostic challenge. Dev Med Child Neurol 2015; 57: 600-610.

[9] Sanger T.D.: Use of Surface Electromyography (EMG) in the Diagnosis of Childhood Hypertonia: A Pilot Study. J Child Neurol 2008; 23: 644-648.

[10] Lumsden D.E., Cadwgan J.: Fifteen-minute consultation: A clinical Approach to the management of the child with hypertonia. Arch Dis Child Educ Pract Ed 2020; 105: 276-281.

[11] World Health Organisation: International classification of functioning, disability and health: ICF Short version. Geneva, Switzerland 2001.

[12] Evans S. H., Cameron M. W., Burton J.M.: Hypertonia. Curr Probl Pediatr Adolesc Health Care 2017; 47: 161-166.

[13] Dy R., Roge D.: Medical Updates in Management of hypertonia. Phys Med Rehabil Clin N Am 2020; 31: 57-68.

[14] Dudek J., Chuchla M., Snela S., et al.: Zmiany wzorca chodu dzieci z mózgowym porażeniem. Przegląd Medyczny Uniwersytetu Rzeszowskiego 2009; 3: 317-332.

[15] Nahm N.J., Graham H.K., Gormley Jr M.E., et al.: Management of hypertonia in cerebral palsy. Curr Opin Pediatr 2018; 30: 57-64.

[16] Sanger T.D.: Hypertonia in children: how and when to treat. Curr Treat Options Neurol 2005; 7: 427-439.

[17] Park T.S., Joh S., Walter D.M., et al.: Selective Dorsal Rhizotomy for the Treatment of Spastic Hemiplegic Cerebral Palsy. Cureus. 2020; 12: e9605.

[18] Park T.S., Joh S., Walter D.M., et al.: Selective Dorsal Rhizotomy for the Treatment of Spastic Triplegic Cerebral Palsy. Cureus. 2020; 12: e9204.

[19] Abbott R.: The selective dorsal rhizotomy technique for spasticity in 2020: a review. Childs Nerv Syst 2020; 36: 1895-1905.

[20] Ayala L., Winter S., Byrne R., et al.: Assessments and Interventions for Spasticity in Infants With or at High Risk for Cerebral Palsy: A Systematic Review. Pediatr Neurol. 2020; S0887-8994(20)30349-0. 